\title{
ES INTEGRACIJOS GALIMYBĖS PILIEČIAMS IR VERSLUI: NAUJAS TEISMŲ SPRENDIMŲ CIVILINĖSE IR KOMERCINĖSE BYLOSE PRIPAŽINIMO BEI VYKDYMO REGLAMENTAVIMAS
}

\author{
Rūta Bučinskaitè \\ Mykolo Romerio universitetas
}

\begin{abstract}
Anotacija
Straipsnyje aptariamas nuo 2015 m. sausio 15 d. įsigaliojęs Reglamentas Nr. 1215/2012 dèl jurisdikcijos bei teismų sprendimų pripažinimo civilinèse ir komercinèse bylose. Kadangi šiuos klausimus ES lygmeniu reglamentavo anksčiau galiojęs reglamentas, straipsnyje atskleidžiama, kaip siūlyta jị keisti, kokie pasiūlymai priimti, vertinama, ar naujos įsigaliojusios taisyklès tikrai užtikrina efektyvų teismų sprendimų pripažinimą ir jų vykdymą, be to, atkreipiamas dėmesys ị problemas, kurių naujos ịsigaliojusios taisyklès neišsprendžia.

PAGRINDINIAI ŽODŽIAI: Europos Sąunga, Reglamentas Nr. 1215/2012, Europos Komisija, bendradarbiavimas civilinèse ir komercinėse bylose, jurisdikcija, teismų sprendimų pripažinimas ir vykdymas.
\end{abstract}

\begin{abstract}
The paper deals with a new Regulation No. 1215/2012, having come into force on 10 January 2015, on jurisdiction and recognition and enforcement of judgements in civil and commercial matters. Since the rules on those matters were included in the previous Regulation at the EU level, the article reveals the proposals made for its amendment, as well as the accepted proposals. It also attempts to evaluate whether the new rules that came into force shall guarantee the effective recognition and enforcement of judgements. The paper identifies the problems which shall not be solved by the newly adopted rules.
\end{abstract}

KEYWORDS: European Union, Regulation No. 1215/2012, European Commission, co-operation in civil and commercial matters, jurisdiction, recognition and enforcement of judgements.

DOI: http://dx.doi.org/10.15181/tbb.v72i3.1165

\section{Ivadas}

Kuriant vieningą Europos Sajungos (toliau - ES) rinką ypač svarbu, kad Europos Sajungos sutarties ir Sutarties dèl Europos Sajungos veikimo nuostatomis efektyviai galètų pasinaudoti ES piliečiai bei ES juridiniai asmenys. Siekiant tokio efektyvaus 4 pagrindinių ES laisvių veikimo, būtini instrumentai, kurie leistų asmenų teises ginti efektyviai ir ekonomiškai.

1968 m. rugsèjo 27 d. Briuselio konvencija dèl jurisdikcijos ir teismų sprendimų pripažinimo civilinėse ir komercinėse bylose ${ }^{1}$ tapo pavyzdžiu, kad suvienodin-

1 Ši konvencija literatūroje dar vadinama ,pagrindiniu akmeniu“ ES civilinio proceso architektūroje (Rauscher, 2006, p. 10). 
tos jurisdikcijos taisyklès civilinėse ir komercinèse bylose, sutarimas dèl teismų sprendimų pripažinimo veikia efektyviai ir leidžia piliečiams bei įmonèms ginti savo teises teisme, tikintis efektyvaus priimtų teismų sprendimų igyvendinimo. Tačiau tik 1997 m. lapkričio 10 d. Amsterdamo sutartis² suteikè kompetenciją ES reglamentuoti teisinị bendradarbiavimą civilinèse ir komercinèse bylose bei derinti proceso teisès normas, siekiant panaikinti kliūtis, kurios trukdo efektyviai bendradarbiauti šioje srityje. İsigaliojus Amsterdamo sutarčiai, ES institucijos buvo ypač aktyvios, priimdamos teisès aktus teisminio bendradarbiavimo srityje. Būtinybe ir toliau aktyviai veikti šioje srityje Europos Komisijai patvirtinta Europos Vadovų tarybai 2009 m. prièmus Stokholmo programą ${ }^{3}$, kuri nustate ES prioritetus teisingumo, laisvès ir saugumo srityje 2010-2014 metams. Igyvendinant Stokholmo programos siekius, peržiūrimas ir galiojantis teisinis reglamentavimas bendradarbiaujant civilinèse ir komercinèse bylose Europos Sajungoje ir priimami nauji - patobulinti instrumentai.

Vienas jų - nuo 2015 m. sausio 10 d. visose Europos Sajungos valstybėse narèse (išskyrus Daniją) pradètas taikyti 2012 m. gruodžio 12 d. Europos Parlamento ir Tarybos reglamentas Nr. 1215/2012 dèl jurisdikcijos ir teismo sprendimų civilinèse bei komercinėse bylose pripažinimo ir vykdymo (toliau - Reglamentas Nr. 1215/2012), pakeitęs 2000 m. gruodžio 22 d. Tarybos reglamentą Nr. 44/2001 dèl jurisdikcijos bei teismo sprendimų civilinèse ir komercinèse bylose pripažinimo bei vykdymo (toliau - Briuselis I). Kadangi reglamentą ${ }^{4}$ tiesiogiai taiko ir Lietuvos teismai, svarbu aptarti Reglamentu Nr. 1215/2012 nustatytus pakeitimus ir naujoves, kurie susiję su jurisdikcijos taisyklèmis, be to, su sprendimų civilinèse ir komercinèse bylose pripažinimu. Net jeigu galiausiai priimtas Reglamentas Nr. 1215/2012 neįtvirtina tokio ambicingo reglamentavimo, kurị siūlè Europos Komisija, tai neabejotinai svarbus žingsnis ị tolesnị sẻkmingą laisvès, saugumo ir teisingumo erdvès harmonizavimą̧.

21997 m. spalio 2 d. Amsterdamo sutartis.

3 Stokholmo programa - atvira ir saugi Europa piliečių labui ir saugumui, priimta Europos Vadovų Tarybos 2010 m. gegužès 4 d.

4 Remiantis Sutarties dẻl Europos Sajungos veikimo 288 straipsniu: „Reglamentas yra taikomas visuotinai. Jis privalomas visas ir tiesiogiai taikomas visose valstybèse narèse."

52014 m. gegužès 15 d. priimtas Reglamentas (ES) Nr. 542/2014, kuriuo dèl taisyklių, taikytinų dèl Bendro patentų teismo ir Beniliukso Teisingumo teismo, iš dalies keičiamas Reglamentas (ES) Nr. 1215/2012. Šio reglamento nuostatos neaptariamos, nes tai susiję su specialiu - patentų teismo klausimu. 


\section{Reglamento Nr. 1215/2012 atsiradimo istorija ir poreikio keisti buvusi teisinị reglamentavimą prielaidos}

Europos Komisija, vykdydama Briuselio I reglamento 73 straipsnyje ịtvirtintą pareigą ne vèliau kaip po penkerių metų nuo šio teisès akto įsigaliojimo pateikti jo taikymo ataskaitą, o prireikus - ir pasiūlymus dèl jo pakeitimo Europos Parlamentui, Tarybai, Ekonomikos ir socialinių reikalų komitetui, $2009 \mathrm{~m}$. balandžio $4 \mathrm{~d}$. pristatè „Žaliają knygą dèl Tarybos reglamento (EB) Nr. 44/2001 dèl jurisdikcijos ir teismo sprendimų civilinėse ir komercinèse bylose pripažinimo ir vykdymo priežiūros “6 (toliau - Žalioji knyga). Tą pačią dieną Europos Komisija patvirtino Briuselis I taikymo ataskaitą ${ }^{7}$, kuri parengta remiantis keliomis su reglamento taikymu susijusiomis mokslinèmis studijomis ${ }^{8}$.

Žaliojoje knygoje pateikti net 8 pasiūlymai: Europos Komisija pasiūlè panaikinti egzekvatūrą, tačiau palikti tam būtiną kontrolę, remiantis $2004 \mathrm{~m}$. balandžio 21 d. Europos Parlamento ir Tarybos reglamento (EB) Nr. 805/2004, sukuriančio neginčytinų reikalavimų Europos vykdomaji raštą ${ }^{9}$, reglamentavimo patirtimi, arba pasinaudoti 2008 m. gruodžio 18 d. Tarybos reglamento (EB) Nr. 4/2009 dèl jurisdikcijos, taikytinos teisès, teismo sprendimų pripažinimo ir vykdymo bei

6 Žalioji knyga del Tarybos reglamento (EB) Nr. 44/2001 dèl jurisdikcijos ir teismo sprendimų civilinèse ir komercinèse bylose pripažinimo ir vykdymo priežiūros COM (2009) 175 galutinis [interaktyvus]. Prieiga internete: http://ec.europa.eu/justice/ newsroom/civil/opinion/files/090630/green_paper_en.pdf [žiūrèta 201506 12, 14 val. $53 \mathrm{~min}$.$] .$

7 Report from the Commission to the European Parliament, the Council and the European economic and social committee on the application of Council Regulation (EC) No 44/2001 on jurisdiction and the recognition and enforcement of judgments in civil and commercial matter, $\operatorname{COM}(2009) 174$ final [interaktyvus]. Prieiga internete: http://ec.europa.eu/justice/newsroom/civil/opinion/files/090630/report_en.pdf [žiūrèta 201506 12, 14 val. $12 \mathrm{~min}$.].

8 Išsamią studiją Europos Komisijos užsakymu 2007 m. rugsèji pateikè prof. Burkhard Hess, prof. Dr. Thomas Pfeiffer ir prof. dr. Peter Schlosser: „Report on the application of Brussels I regulation in the Member States" [interaktyvus]. Prieiga internete: http:// ec.europa.eu/civiljustice/news/docs/study_application_brussels_1_en.pdf [žiürèta 201505 01, 12 val. $5 \mathrm{~min}$.].

Kitos studijos, kuriomis Europos Komisija rèmėsi teikdama Žaliają knygą: Studija dèl nacionaliniu jurisdikcijų taisyklių, kai atsakovas negyvena valstybejje narèje (Nuyts ataskaita) [interaktyvus]. Prieiga internete: http://ec.europa.eu/civiljustice/news/docs/ study_residual_jurisdiction_en.pdf [žiūrèta 201505 01, 13 val. 21 min.]. Studija dèl tikslingumo Europos Sajungai ratifikuoti Hagos konvenciją dèl teismo pasirinkimo susitarimu [interaktyvus]. Prieiga internete: http://ec.europa.eu/dgs/justice_home/ evaluation/dg_coordination_evaluation_annexe_en.htm [žiūrèta 201405 06, 19 val. $35 \mathrm{~min}]$.

9 OJ L 143, 2004.04.30, p. 15-39, specialus leidimas lietuvių kalba. 
bendradarbiavimo išlaikymo prievolių srityje ${ }^{10}$ sukurto mechanizmo moduliu, kai atsakovas turi specialios peržiūros a posteriori galimybę. Žaliojoje knygoje siūlyta plèsti Briuselis I taikymą tarptautinèje erdveje ir nustatyti unifikuotas subsidiarios jurisdikcijos taisykles atsakovams, esantiems ne ES valstybėse narèse. Pasiūlyta ir priemonių, kurios galètų padèti efektyviau susitarti dẻl teismingumo galiojimo, leistų efektyviai apsaugoti pramoninę nuosavybę, ir priemonių, padėsiančių užtikrinti efektyvų lis pendens taisyklès veikimą. Kadangi Briuselis I taikymo praktikoje laikinujų apsaugos priemonių laisvas judejjimas kẻlè rimtų praktinių problemų (Maher, Roger, 2000, p. 302; Palsson, 2000, p. 621), Žaliojoje knygoje pasiūlyta aiškiau reglamentuoti teismų sprendimų dèl laikinụjų apsaugos priemonių pagal Briuselis I reglamentą pripažinimą. Dèl vis didèjančios arbitražo reikšmès verslui siūlyta tobulinti reglamento nuostatas, kurios padètų užtikrinti dar efektyvesnị 1958 m. Niujorko konvencijos taikymą. Žaliojoje knygoje pateikti pasiūlymai ir dẻl reglamento taikymo apimties susiaurinimo, iš jos aiškiai išskiriant su išlaikymo prievolèmis susijusius ginčus, pateiktas siūlymas apsvarstyti autonominès nuolatinés gyvenamosios vietos (ang. domicile) sąvokos apibrěžimo su aiškiais kriterijais ịtvirtinimą, ịtvirtinti autentiškų instrumentų laisvą judejjimą teismo sprendimų pripažinimo ir vykdymo stadijoje.

Paskelbus Žaliają knygą, konsultacijos su valstybėmis narėmis ir suinteresuotais asmenimis truko nuo 2009 m. balandžio 21 d. iki birželio 30 d. Per šị trumpą laiką iš viso gauti 138 atsiliepimai dẻl Europos Komisijos parengtos Žaliosios knygos, taip tarsi patvirtinant, kad Briuselis I reglamentuojama sritis yra svarbi ir teisèkūros procesas Europos Sajungos institucijose negalèjo būti paprastas bei greitas.

Savo nuomonę dẻl Žaliosios knygos pateikè ir Lietuvos Respublikos teisingumo ministerija ${ }^{11}$. Iš pateiktų atsakymų atkreiptinas dẻmesys ị išsakytą nuomonę dẻl specialios jurisdikcijos taisyklių trečiųjų valstybių atžvilgiu taikymo, atsakyme nurodyta, kad tokių taisyklių taikymas gali būti sudètingas ir mažai veiksmingas. Naujojo reglamento teisėkūros procese šis klausimas ypač aktualus ir būtent tokios nuomonès laikèsi daugelis valstybių narių atstovų. Lietuvos atsiliepimuose siūlyta svarstyti galimybę suteikti bylą iš esmės nagrinejjančiam teismui kompetenciją panaikinti kitų teismų, kuriems byla nebūtų teisminga iš esmès, priimtas nutartis dèl laikinujų apsaugos priemonių taikymo. Toks pasiūlymas vertintinas kaip labai drąsus ir novatoriškas, jo prièmimas būtų išties reikšmingai prisidèjęs prie ES valstybių narių efektyvaus bendradarbiavimo civilinèse ir komercinèse bylose.

İvertinusi visus pateiktus pasiūlymus, 2010 m. gruodžio 14 d. Europos Komisija pateikè „Pasiūlymą dèl Europos parlamento ir Tarybos reglamento dèl ju10 OJ L 7, 2009.10.01, p. 1-79.

112009 m. liepos 4 d. raštas Nr. (1.11) 7R-5198 [interaktyvus]. Prieiga internete: http://ec.europa.eu/justice/newsroom/civil/opinion/090630_en.htm [žiūrèta 20150107,11 val. $20 \mathrm{~min}$.]. 
risdikcijos ir teismo sprendimų civilinèse ir komercinėse bylose pripažinimo ir vykdymo"12 (toliau - Komisijos pasiūlymas). Toliau straipsnyje aptariami pakeitimai, kuriuos siūlè Europos Komisija ir galutinis Reglamentu Nr. 1215/2012 įtvirtintas reglamentavimas.

\section{Komisijos pasiūlymas ir Reglamento Nr. 1215/2012 nuostatos}

\subsection{Egzekvatūros panaikinimas ir Reglamento Nr. 1215/2012 taisyklès}

Remiantis reglamentu Briuselis I, svarbu atskirti teismų sprendimų pripažinimą ir jų vykdymą, pastarasis, nepaisant jau ịvykusio teismo sprendimo pripažinimo, iki šiol buvo galimas tik teismo sprendimą paskelbus vykdytinu pagal Briuselis I 38 straipsnyje numatytą procedūrą, vadinamą egzekvatūra (procedūra, kurios tikslas - suteikti vykdytinumą vienoje valstybejje nareje priimtam teismo sprendimui kitoje nei jo kilmès valstybèje nareje). Būtent panaikinti šią procedūrą siekta tobulinant reglamento Briuselis I nuostatas.

Egzekvatūros panaikinimo tikslas - „kad valstybejje narëje priimtas teismo sprendimas turètų būti pripažintas visose valstybèse narèse netaikant jokios specialios procedūros. Be to, siekis sumažinti tarptautinio bylinëjimosi laiko sąnaudas ir išlaidas pateisina teismo sprendimo paskelbimo vykdytinu, prieš pradedant ji vykdyti valstybẻje narèje, ị kurią kreipiamasi, panaikinimą. Todẻl vienos valstybės narès teismo sprendimas turètų būti traktuojamas taip, tarsi jis būtų priimtas valstybejje nareje, ị kurią kreipiamasi“"13. Egzekvatūros panaikinimas buvo Europos Komisijos tikslas jau pristatant Žaliają knygą, o Komisijos pasiūlyme jis pagrịstas tuo, kad vidutiniškai visoje ES 93 procentai prašymų pripažinti teismo sprendimus yra patenkinami, tik 5 procentai tokių sprendimų yra skundžiami apeliacine tvarka, tačiau apeliaciniai skundai dažniausiai būna nesėkmingi “14. B. Hess, T. Pfeiffer, P. Schlosser ataskaitoje (Hess, Pfeiffer, Schlosser, 2007, p. 21) pateikti duomenys atskleidè, kad daugiau nei 90 procentų (dažnai 100 procentų) visų prašymų sprendimus pripažinti vykdytinais pagal Briuselis I 38 straipsnio 1 dalị būna sèkmingi, tačiau tokie prašymai dažnai būna nevisiškai užpildyti, todèl valstybių narių institucijos, turinčios kompetenciją pripažinti sprendimus vykdytinais, dažnai prašo

122010 m. gruodžio 14 d. KOM (2010) 748 galutinis [interaktyvus]. Prieiga internete: http://eur-lex.europa.eu/legal-content/EN/TXT/?qid=1419152097677\&uri=CELEX:5 2010PC0748 [žiūrèta 20150107,11 val. 20 min.].

13 Reglamento Nr. 1215/2012 26 konstatuojamoji dalis.

142010 m. gruodžio 14 d. Komisijos tarnybų darbinis dokumentas „Poveikio vertinimo ataskaita“, SEC(2010) 1547 galutinis, 12 p. [interaktyvus]. Prieiga internete: http:// ec.europa.eu/justice/policies/civil/docs/sec_2010_1547_en.pdf [žiūrèta 20140107 , 11 val. $20 \mathrm{~min}$.]. 
prašymus papildyti, ypač kai tai susiję su vertimų pateikimu. Tokio prašymo patenkinimas valstybėje narèje, kurioje sprendimą siekiama ịvykdyti, užtrunka nuo 7 kalendorinių dienų iki 4 mènesių.

Komisija siūlè nurodyti, kad „vienoje valstybèje nareje priimtas sprendimas, kuris yra vykdytinas toje valstybejje nareje, vykdytinas ir kitoje valstybejje narejje, nereikalaujant jo paskelbti vykdytinu“. Reglamento Nr. 1215/2012 39 straipsnyje nustatyta, kad „vienoje valstybëje narëje priimtas teismo sprendimas, kuris yra vykdytinas toje valstybejje nareje, yra vykdytinas kitoje valstybejje narèje ir tam nereikia jo skelbti vykdytinu“. Taigi valstybių narių apsisprendimas panaikinti egzekvatūrą įrodo išaugusị valstybių narių tarpusavio pasitikejimą, kuris yra būtinas siekiant užsibrež̌to teisminès gynybos prieinamumo įgyvendinimo ES; tai turètų padèti sutrumpinti teismo sprendimų vykdymo terminus, taupyti vertimo ir teisinio atstovavimo išlaidas (Alio, 2014, p. 2395), nes Reglamente Nr. 1215/2012 nereikalaujama, kad pareiškejjas nurodytų adresą, kuriuo turètų būti ịteikiami teismo dokumentai to teismo, ị kurị kreipiamasi, jurisdikcijoje - iki įsigaliojant Reglamentui Nr. 12152012 tuo atveju, jei valstybès, kurioje prašoma vykdyti sprendimą, i̊statymuose nenustatytas tokio adreso pateikimas, pareiškejjas turèdavo paskirti atstovą ad litem; taigi, panaikinus Briuselis I 40 straipsnio 2 dalyje buvusị reikalavimą, praktiškai palengvejja teismo sprendimo vykdymas, nes asmeniui, kuris neturi nuolatinès gyvenamosios vietos valstybeje nareje, kurioje siekia teismo sprendimo ịvykdymo, nereikia samdyti atstovo, kuris galètų suteikti adresą.

\subsection{Teismo sprendimo pripažinimas ir vykdymas: svarbiausios Reglamente Nr. 1215/2012 įtvirtintos naujovès}

\subsubsection{Teismo sprendimo pripažinimas}

Reglamente Nr. 1215/2012, kaip ir Briuselis I, ịtvirtintas automatinis teismo sprendimų pripažinimas (Reglamento Nr. 1215/2012 36 straipsnio 1 dalis), tačiau bet kuri suinteresuotoji šalis gali prašyti priimti sprendimą, kuriame būtų konstatuojama, kad nèra pagrindų atsisakyti pripažinti teismo sprendimą, t. y. nėra pagrindų, nurodytų Reglamento Nr. 1215/2001 45 straipsnyje. 45 straipsnyje nustatytas atsisakymo pripažinti (ir vykdyti) pagrindų sąrašas nuo Briuselis I 34 ir 35 straipsniuose įtvirtintų atsisakymo pripažinti teismo sprendimą pagrindų skiriasi tuo, kad (i) atsisakoma pripažinti, kai buvo pažeistos jurisdikcijos taisyklès bylose, kurios susijusios su individualiomis darbo sutartimis, t. y. papildytas pagrindų sąrašas; (ii) jei jurisdikcijos taisyklès pažeistos bylose, kurios susijusios su individualiomis darbo sutartimis, draudimu, vartotojų teisių apsauga, tai sudaro kliūtị teismo sprendimą pripažinti tik tuo atveju, jei atsakovu buvo draudèjas, ap- 
draustasis, draudimo sutarties naudos gavejjas, žalą patyrusi šalis, vartotojas arba darbuotojas, t. y. silpnesnioji teisinių santykių šalis.

\subsubsection{Teismo sprendimo vykdymas}

Kad atsirastų prielaidos vykdyti teismo sprendimą, pirmiausia jis turi būti priimtas. Atkreiptinas demesys, kad Reglamente Nr. 1215/2012 2 straipsnio a punkte pateiktas „teismo sprendimo“ apibrèžimas yra platesnis, nei „teismo sprendimo“ apibrěžimas Briuselis I 32 straipsnyje. Remiantis Reglamentu Nr. 1215/2012, ị teismo sprendimo sampratą patenka ir teismo, kuris, remiantis reglamentu, turi jurisdikciją nagrinèti bylą iš esmès, paskirtos laikinosios priemonès, įskaitant apsaugos priemones; prieš priimant tokị sprendimą, atsakovas turi būti pakviečiamas i teismą arba teismo sprendimas jam turi būti įteiktas prieš pradedant ji vykdyti. Taigi teismų nutartys dèl laikinujų apsaugos priemonių taip pat bus tiesiogiai vykdytinos be jokios papildomos procedūros. Teisinèje literatūroje ${ }^{15}$ atkreipiamas dèmesys, kad Reglamente Nr. 1215/2012 tiesiogiai nenurodyta, kad vykdytinas sprendimas dèl laikinujų apsaugos priemonių taikymo turi turèti teisinę galią, t. y. būti neskundžiamas kilmès valstybejje nareje, nes toks pagrindas 46 straipsnyje nenumatytas. Teisinejje literatūroje pažymima (Alio, 2014, p. 2397), kad tokia Reglamento Nr. 1215/2012 nuostata atitinka ir jo kūrejjų tikslus, nes taip taupomas laikas ir piniginiai teismo sprendimo vykdymo ištekliai. Anksčiau galiojusio Briuselis I reglamento 47 straipsnis suteikè teisę valstybejje narẻje, kurioje turès būti vykdomas teismo sprendimas, suinteresuotai sprendimo vykdymu proceso šaliai prašyti laikinųjų apsaugos priemonių tuo laikotarpiu, kol vyks teismo sprendimo pripažinimas. Tokia procesine galimybė išlieka ir Reglamente Nr. 1215/2012, tai nustatyta 40 straipsnyje, tačiau panaikinus egzekvatūros procedūrą, tokių nutarčių poreikis turètų mažèti, taigi turètų mažèti ir šalių bylinėjimosi sąnaudos.

Neabejotinai svarbiu iššūkiu taps Reglamento Nr. 1215/2012 54 straipsnio nuostata, numatanti, kad jei teismo sprendime numatyta priemone arba ịsakymas, kuris, remiantis valstybės narės, ị kurią kreipiamasi, teise, nežinomas, ta priemonė arba ịsakymas prilyginami tos valstybès narès teisèje žinomai priemonei arba įsakymui, kurie turi lygiavertị poveikị ir kuriais siekiama panašių tikslų bei interesų. Ši nuostata nedetalizuoja, kaip paskirtą priemonę pritaikyti vykdymo vietos valstybeje nareje, taip pat nenurodo, kas tai turètų atlikti. Lietuvoje tai gali kelti realių vykdymo problemų, nes, pavyzdžiui, nutartis dèl laikinųjų apsaugos priemonių vykdo ne vienas subjektas - antstoliai, valstybinès institucijos (viešajame registre įrašą atlieka registrus administruojančios institucijos). Neapibrèžta, kas turètų nuspręsti, koks ịrašas turi būti lietuviškame viešajame registre, jei nutartyje numatyto

15 Vartojamas terminas rechtskraeftig, kuris verčiamas kaip turintis teisinę galią. 
įrašo rūšies lietuviškame registre apskritai nèra. Tokia situacija neabejotinai palanki skolininkui: jis galès skųsti kiekvieną vykdymo veiksmą, nurodydamas, kad parinkta priemonè neadekvati tai, kuri paskirta. Galiausiai teismai turès vertinti, kokios priemonès yra funkciškai adekvačios, tačiau kiekvienu atveju teismo procesas neleis užtikrinti operatyvaus tokių laikinujų apsaugos priemonių taikymo.

Manytina, kad siekiant vieno pagrindinių laikinujų apsaugos priemonių tikslų - operatyvaus jų taikymo ir kreditoriaus interesų apsaugos, Europos Sajungos ịstatymų leidèjui tikslinga svarstyti galimybę sukurti pavyzdinį laikinujų apsaugos priemonių sąrašą, taikytiną pagal Reglamento Nr. 1215/2012 54 straipsnị, dèl kurio sutartų visos valstybės narès ir kuris galètų tapti pagrindu visų valstybių narių institucijoms taikyti laikinąsias apsaugos priemones. Tai leistų išvengti ginčų, sprendžiant, ar valstybės narès taikoma laikinoji apsaugos priemonė yra lygiavertė tai, kurią numato teismo sprendimas. Be to, lygiavertiškumo kriterijų formulavimas teismų praktikoje - ilgas procesas, todèl manytina, kad tokio priemonių sąrašo sukūrimas leistų efektyviau taikyti laikinąsias apsaugos priemones.

Lietuvos Respublikos Civilinį procesą reglamentuojančių Europos Sajungos ir Tarptautinès teisès aktų ịgyvendinimo ịstatymo 43 straipsnis nustato, kad „1. Vadovaujantis Reglamento (ES) Nr. 1215/2012 54 straipsnio 1 dalimi, teismo sprendime numatytą priemonę ar ịsakymą prilygina subjektas, kuris turi pripažinti ar vykdyti teismo sprendimą. 2. Priemonès arba ịsakymo prilyginimas gali būti užginčijamas teisme Lietuvos Respublikos ịstatymų nustatyta tvarka"16. Taigi įstatymo kūrèjui Lietuvoje nesukūrus specialios procedūros ar bent jau nenumačius specialių - trumpesnių terminų tokiems ginčams nagrinèti, darytina išvada, kad praktinis Reglamento Nr. 1215/2012 54 straipsnio nuostatų veikimas bus apsunkintas ginčų nacionaliniuose teismuose dèl to, kas laikytina lygiaverte poveikio priemone ir kaip ji turètų būti taikoma.

Kreditorių interesų apsauga teismo procese, siekiant taikyti laikinąsias apsaugos priemones, turètų palengvèti nuo $2017 \mathrm{~m}$. sausio $18 \mathrm{~d}$., kada ịsigalios $2014 \mathrm{~m}$. gegužès 15 d. Europos Parlamento ir Tarybos Reglamentas (ES) Nr. 655/2014, kuriuo nustatoma europinio sąskaitos blokavimo įsakymo procedūra, siekiant palengvinti tarpvalstybinị skolų išieškojimą civilinèse ir komercinèse bylose ${ }^{17}$. Šis reglamentas sukuria alternatyvią laikinają apsaugos priemonę, kurią kreditoriai galès rinktis teisme tarpvalstybinès bylos atveju prašydami valstybès narès teismo, kuris turi jurisdikciją nagrinèti bylą iš esmès, bet kuriuo proceso metu priimti

16 Lietuvos Respublikos civilini procesą reglamentuojančių Europos Sajungos ir tarptautinès teisès aktų igyvendinimo ịstatymas (Žin., 2008, Nr. 137-5366), redakcija, galiojanti nuo $2015 \mathrm{~m}$. rugpjūčio $17 \mathrm{~d}$.

172014 m. gegužès 15 d. Europos Parlamento ir Tarybos Reglamentas (ES) Nr. 655/2014, kuriuo nustatoma europinio sąskaitos blokavimo įsakymo procedūra, siekiant palengvinti tarpvalstybinị skolų išieškojimą civilinèse ir komercinèse bylose, 59-93. 
europinį sąskaitos blokavimo įsakymą, tai bus pagrindas areštuoti atsakovo banko sąskaitas, esančias visuose prie reglamento prisijungusių valstybių narių bankuose (Didžiojoje Britanijoje ir Danijoje šis reglamentas nebus taikomas) be jokios papildomos tarpinès pripažinimo procedūros.

Vykdymo procesą Reglamente Nr. 1215/2012 nustatančios taisyklès iš esmès apverčia situaciją, nes sprendimas, priimtas vienoje valstybejje nareje, vykdytinas ir kitoje valstybejje nareje. Priešingai nei pagal galiojusias Briuselis I nuostatas, pagal kurias ieškovas, gavęs ji tenkinantị teismo sprendimą, dar turèdavo kreiptis dèl jo paskelbimo vykdytinu jo vykdymo valstybejje nareje, pagal naujas taisykles atsakovas turi kreiptis į teismą tam, kad būtų atsisakyta vykdyti teismo sprendimą. Be to, dabar teismo sprendimo kilmès valstybès narès teismas, išduodamas Reglamento Nr. 1215/2012 V priede patvirtintos formos pažymą, patvirtina, kad sprendimas yra vykdytinas - priešingai nei pagal galiojusias Briuselis I nuostatas, kai teismo sprendimą vykdytinu turi paskelbti valstybès narès, kurioje jis bus vykdomas, teismas.

Tiek pateikiant vykdyti teismo sprendimą iš esmès, tiek teismo sprendimą dèl laikinụjų apsaugos priemonių taikymo, turès būti pateikta teismo sprendimo kopija, kurios autentiškumą galima patvirtinti (Reglamento Nr. 1215/2012 42 straipsnio 1 dalies a punktas ir 2 dalies a punktas), taip pat pažyma, nurodyta Reglamento Nr. 1215/2012 I priede, kurioje nurodyta, kad teismo sprendimas vykdytinas, pateikiama jo santrauka ir nurodomos visos mokètinos sumos. Atkreiptinas dèmesys, kad, palyginus su pažyma, kuri numatyta Briuselis I V priede, Reglamento Nr. 1215/2012 priede numatyta pažyma yra daug išsamesne, joje reikalaujama pateikti nemažai informacijos, kuri atskleidžia teismo sprendimo esmę ${ }^{18}$.

Reglamento Nr. 1215/2012 42 straipsnis nustato, kokius dokumentus kompetentingai institucijai turi pateikti asmuo, siekdamas įvykdyti teismo sprendimą, priimtą kitoje valstybejje narejje: teismo sprendimo kopiją, atitinkančią sąlygas, būtinas jo autentiškumui patvirtinti, ir I reglamento priedu patvirtintos formos bei turinio pažymą, kuria patvirtinama, kad teismo sprendimas vykdytinas, be to, pažymą, kurioje pateikiama teismo sprendimo santrauka ir (atitinkamais atvejais) informacija apie atlygintinas bylinejjimosi išlaidas bei palūkanų apskaičiavimą. Ši

18 Remiantis Reglamentu Nr. 1215/2012, turi būti nurodyti išsamūs duomenys apie ieškovą ir atsakovą - ne tik pavadinimas, bet ir adresas, gimimo arba registracijos data, kontaktiniai duomenys. Be to, teismo sprendimas turi būti apibūdintas išsamiai, nurodant, ar bylos nagrinejjime dalyvavo atsakovas, ar jam buvo įteiktas teismo sprendimas. Svarbiausi pakeitimai, susiję su teismo sprendimo esmès apibūdinimu, pažymą išduodantis teismas turés nurodyti, kokios mokètinos sumos priteistos ir kada jos turi būti sumokètos (jei mokèjimai turi būti periodiniai), turi būti nurodytas ir mokètinų palūkanų dydis. Pažymoje turès būti konkretizuotos išlaidos, kurias prašoma išieškoti (žyminis mokestis, teisinio atstovavimo išlaidos). 
pažyma sudaro sprendimo vykdymo proceso esmę, nes ją pildys kilmės valstybės narès teismas ir tai turi būti atlikta taip, kad kitos valstybės narès kompetentinga institucija galètų teismo sprendimą vykdyti. Papildomai teismas, prièmęs sprendimą, turès nurodyti informaciją, kuri susijusi su skolos suma, mokejjimo terminu, valiuta, be to, nurodyti palūkanų dydị. Sprendimą vykdančios institucijos, remdamosi Reglamento Nr. 1215/2012 42 straipsnio 3 dalimi, prireikus galès reikalauti pažymos turinio vertimo arba transliteracijos, o paties sprendimo vertimo reikalauti turès teisę tik tuo atveju, jei be jo negalès vykdyti tolesnių veiksmų, taigi, toks reglamentavimas iš esmès apriboja vykdančiosios institucijos teisę reikalauti teismo sprendimo vertimo. Tikètina, kad toks reglamentavimas supaprastins ir palengvins teismo sprendimų vykdymą Europos Sajungoje, nes ịprasto teismo sprendimo atveju jo vertimas nebūtinas, tokị teismo sprendimą galima vykdyti ir neturint viso jo vertimo, svarbiausia, kad pažymoje aiškiai būtų matomos išieškotinos sumos (Alio, 2014, p. 2397).

Prieš pradedant bet kuriuos vykdymo veiksmus, remiantis Reglamento Nr. 1215/2012 43 straipsniu, pažyma turi būti ịteikta asmeniui, prieš kurị nukreipiamas teismo sprendimo vykdymas. Jei teismo sprendimas asmeniui neįteiktas, jis turès būti įteiktas kartu su pažyma. Reglamento Nr. 1215/2012 43 straipsnis nustato vertimo taisykles - $\mathfrak{i}$ kokią kalbą dokumentai turètų būti išverčiami, tačiau tiek pažymos, tiek teismo sprendimo, kaip teisminių dokumentų, ịteikimas turètų būti vykdomas pagal 2007 m. lapkričio 13 d. Europos Parlamento ir Tarybos reglamentą (EB) Nr. 1393/2007 dèl teisminių ir neteisminių dokumentų civilinėse ir komercinèse bylose ịteikimo valstybėse narèse (dokumentų įteikimas), panaikinantis Tarybos reglamentą (EB) Nr. 1348/2000 ${ }^{19}$ (toliau - Reglamentas Nr. 1393/2007). Reglamentas Nr. 1393/2007 nustato ne tik įteikimo, bet ir dokumentų vertimo taisykles, kurias jau yra aiškinęs Europos Sajungos Teisingumo Teismas (toliau - ESTT ${ }^{20}$ ). Remiantis Reglamento Nr. 1215/2012 43 straipsnio 2 dalimi, asmuo, prieš kurị nukreiptas teismo sprendimas, jei jo nuolatiné gyvenamoji vieta yra ne teismo sprendimo kilmès valstybèje narèje, gali prašyti pateikti teismo sprendimo vertimą, jei jis surašytas ne ta kalba, kurią jis supranta, arba valstybės narės, kurioje yra jo nuolatinė gyvenamoji (buveinès) vieta, oficialiaja kalba. Analogiška taisyklè nustatyta ir Reglamento Nr. 1393/2007 8 straipsnio 1 dalyje. Manytina, kad Reglamento rengèjai galëjo tiesiog pateikti nuorodą ị Reglamentą Nr. 1393/2007, nes dvigubas taisyklès įtvirtinimas ateityje abu reglamentus taikysiantiems teismams gali sukel-

19 OJ L 324, 2007.12.10, p. 79-120.

20 Pavyzdžiui, 2012 m. gruodžio 19 d. Europos Sajungos Teisingumo Teismo sprendimas Nr. C325/11, ECLI:EU:C:2012:824; 2012 m. kovo 15 d. sprendimas Nr. C292/10 byloje G. prieš Cornelius de Visser, ECLI:EU:C:2012:142; 2009 m. birželio 25 d. sprendimas Nr. C-14/08, priimtas byloje Nr. Roda Golf \& Beach Resort SL, ECLI:EU:C:2009:395. 
ti ịvairių probleminių situacijų ${ }^{21}$. Pažymėtina, kad reikalavimas įteikti asmeniui pažymą ir teismo sprendimą netaikomas nutartims ir sprendimams dẻl laikinujų apsaugos priemonių taikymo pagal Reglamento Nr. 1215/2012 40 ir 43 straipsnio 3 dali, taigi taip sudaromos prielaidos efektyviai taikyti laikinąsias apsaugos priemones, priimtas nepranešus atsakovui.

\subsubsection{Skolininku interesu apsauga}

Akivaizdu, kad pagereja kreditorių galimybės greičiau ir pigiau igyvendinti Europos Sajungos teismų sprendimus kitoje nei šių sprendimų kilmės valstybejje nareje. Tačiau viešasis interesas reikalauja, kad būtų užtikrinta ir atsakovo teisių apsauga. Pirmiausia ji užtikrinama valstybès narès nacionalinėmis teisès normomis ginčą nagrinejjant iš esmès, kai atsakovas turi galimybę atsikirsti ir prieštarauti.

Sprendimo ịgyvendinimo etape skolininko interesų apsaugai ịtvirtinta kita procedūra - teisès teikti prašymą dèl atsisakymo vykdyti teismo sprendimą nustatymas. Lietuvoje tokius prašymus nagrinès Lietuvos apeliacinis teismas, o teismo sprendimui nepripažinti nustatytas tradicinis, tik šiek tiek papildytas pagrindų sąrašas: prieštaravimas viešajai tvarkai, atsakovo neinformavimas apie procesą, dèl kurio pastarasis prarado teisę ị teisminę gynybą, prašomo vykdyti teismo sprendimo nesuderinamumas su vykdymo valstybejje nareje priimtu teismo sprendimu tarp tų pačių šalių ar su ankstesniu teismo sprendimu, priimtu kitoje valstybejje narejje, taip pat imperatyvių jurisdikcijos taisyklių nesilaikymas ${ }^{22}$.

\section{3. „Senos naujos“ jurisdikcijos taisyklès}

\subsection{1. Žalioji knyga ir Komisijos pasiūlymas}

Komisija jau Žaliojoje knygoje nurodè, kad siekiant tinkamo vidaus rinkos veikimo reikia užtikrinti vienodai efektyvų teisès ị teisminę gynybą ịgyvendinimą vidaus rinkoje ir tarptautiniu lygiu ne tik atsakovams, bet ir ieškovams, kurių nuolatinè gyvenamoji ar veiklos vieta yra Europos Sajungoje. Komisija nurodé, kad vienodos jurisdikcijos taisyklès santykiuose su atsakovais iš trečiụjų šalių susti-

21 Pavyzdžiui, ar teismams bus privalomi ESTT išaiškinimai dẻl kalbos, kuriuos ESTT pateike aiškindamas Reglamentą Nr. 1393/2007.

22 Atkreiptinas dèmesys, kad nuostata dèl specialios jurisdikcijos nesilaikymo taikytina tik tuo atveju, kai atsakovas buvo draudejas, apdraustasis, draudimo sutarties naudos gavejjas, žalą patyrusi šalis, vartotojas arba darbuotojas. Tai numatyta Reglamento Nr. 1215/2012 45 straipsnio 1 dalyje. 
printų Europos Sajungos piliečių ir verslo subjektų apsaugą bei garantuotų privalomų Europos Sajungos taisyklių laikymąsi ${ }^{23}$. Komisija pabrèžè būtinybę spręsti, kokios jau egzistuojančios jurisdikcijos taisyklès turètų būti taikomos atsakovų iš trečiujų valstybių narių atžvilgiu, taip pat subsidiarių jurisdikcijos taisyklių poreikį. Be to, Žaliojoje knygoje nurodyta, kad toks jurisdikcijos taisyklių taikymo išplètimas padidintų paraleliai vykstančių procesų skaičių, todèl svarbu nuspręsti, kokiais atvejais teismo procesas, pradètas Europos Sajungos valstybejje narejje, turètų būti tęsiamas, nepaisant paraleliai vykstančio teismo proceso trečiojoje valstybejje narejje, be to, turètų būti suderintos trečiosiose valstybèse narèse priimtų teismų sprendimų pripažinimo ir vykdymo taisyklès.

Teikdama pasiūlymą jurisdikcijos klausimais Komisija buvo labai ambicinga (Cadet, 2013, p. 219): siūlè, kad vartotojams, darbuotojams ir draudejjams skirtos apsauginès jurisdikcijos taisyklès būtų taikomos ir tada, kai atsakovas gyvena ne ES. Tokia taisyklè ypač aktuali tais atvejais, kai ieškovui, kurio nuolatinè gyvenamoji vieta yra ES valstybejje narejje, dėl trečiosios valstybės narès galiojančių jurisdikcijos taisyklių nesuteikiama teisè reikšti ieškinị (Alio, 2014, p. 2397) ${ }^{24}$. Be to, Komisija siūlè ịtvirtinti du papildomus ginčų sprendimo institutus tais atvejais, kai atsakovas gyvena ne ES: pirma, galimybė ne ES gyvenantị atsakovą paduoti ị teismą jam priklausančio kilnojamojo turto buvimo vietoje, jei jo vertė neproporcinga ieškinio vertei, o ginčas gana glaudžiai susijęs su teismo, kuriame iškelta byla, valstybe nare ${ }^{25}$; antra, siūlyta ịtvirtinti forum necessitatis taisyklę ir nustatyti, kad valstybės narès teismai galès pasinaudoti jurisdikcija, jei nėra jokio kito teismo, užtikrinančio teisę ị teisingą bylos nagrinèjimą, o ginčas gana glaudžiai susijęs su atitinkama valstybe nare ${ }^{26}$. Galiausiai siūlyta ịtvirtinti diskrecinę lis pendens taisyklę, taikomą ginčams dèl to paties dalyko ir tarp tų pačių šalių, kurie yra ES ir trečiosios šalies teismų žinioje, nurodant, kad valstybès narès teismas gali sustabdyti bylos nagrinèjimą, jei byla pirmiau iškelta ES nepriklausančios šalies teisme, kuris, tikètina, priims sprendimą per protingą terminą ir jị bus galima pripažinti bei vykdyti toje valstybejje narèje.

23 Žalioji knyga, 4 p. [interaktyvus]. Prieiga internete: http://www.ipex.eu/IPEXLWEB/dossier/document.do code $=$ COM\&year $=2009 \&$ number $=0175 \&$ extension $=F I N$ [žiūrèta 201509 02, 17 val. 10 min.].

24 Taip gali įvykti, kai, pavyzdžiui, darbuotojo ginče su darbdaviu nustatoma, kad jurisdikcija nustatoma pagal darbuotojo gyvenamają vietą; tačiau jei darbuotojas neturi nuolatinès gyvenamosios vietos trečiojoje valstybèje narejje, jis netenka galimybès kreiptis i teismą.

25 Komisijos pasiūlymo 25 straipsnis.

26 Komisijos pasiūlymo 26 straipsnis. 


\subsubsection{Jurisdikcijos taisykliu taikymas asmenu iš trečiujų šaliu atžvilgiu}

Toks platus ir visaapimantis jurisdikcijos taisyklių taikymo išplètimas nebuvo priimtas (Cadet, 2013, p. 219; Alio, 2014, p. 2397). Jurisdikcijos taisyklių taikymo išplètimas atsakovams iš trečiujų šalių - politiškai labai jautrus klausimas, todèl būtų tikslinga tokių taisyklių egzistavimą aptarti su trečiosiomis valstybèmis, užuot vienašališkai nustačius jų taikymą ir pasekmes. Nẻ vienas iš Komisijos siūlytų papildomų ginčų sprendimo institutų (jurisdikcija pagal atsakovui priklausančio kilnojamojo turto buvimo vietą ir forum necessitatis) nebuvo priimti, kas vertintina neigiamai, nes šių taisykliụ įtvirtinimas būtų leidęs supaprastinti reikalavimų atsakovams iš trečiųjų valstybių narių ịvykdymą (Alio, 2014, p. 2397). To priežastis ta, kad tiek Europos Parlamentas, tiek didelẻ dalis valstybių narių sprendè, jog toliau jurisdikcijos taisykles santykiuose su atsakovais iš trečiųų šalių šioje srityje turetų vienodinti Hagos privatinès teisès konferencija ${ }^{27}$.

Galiojusios išimtinès jurisdikcijos taisyklès, nepaisant to, kur yra ieškovo ar atsakovo nuolatinè gyvenamoji (buveinès) vieta, ir toliau lieka galioti - jos ịtvirtintos Reglamento Nr. 1215/2012 24 straipsnyje. Toliau apžvelgiami pagrindiniai su jurisdikcijos taisyklèmis susiję pakeitimai, įtvirtinti Reglamente Nr. 1215/2012.

Reglamento Nr. 1215/2012 21 straipsnio 2 dalis ịtvirtina naujovę: nustatyta, kad darbdaviui, kurio nuolatinè gyvenamoji (buveinès) vieta yra ne valstybeje narejje, ieškinys gali būti pareikštas valstybės narès, kurioje darbuotojas paprastai atlieka savo darbą arba paskutinès tokios vietos teisme, o jei darbas buvo atliekamas ne toje pačioje šalyje - vietos, kurioje yra ar buvo darbuotoją įdarbinusi įmonè. Kad būtina taikyti šias jurisdikcijos taisykles atsakovams iš trečiųų valstybių, mane tiek Europos Taryba, tiek Europos Parlamentas; tai - apsauga darbuotojui, kuris, kaip silpnesnioji ginčo šalis, pagal anksčiau galiojusias Briuselis I nuostatas negalëjo kreiptis ị teismą valstybejje narèje, kurioje nuolatos dirba, arba ten, kur buvo įdarbintas, nors faktiškai tokios valstybès narès teismas ir teisinis santykis, susiklostęs tarp darbuotojo ir darbdavio, yra glaudžiai susiję (Cadet, 2013, p. 220).

\subsubsection{Susitarimu dèl jurisdikcijos efektyvumo didinimas}

Kitas svarbus jurisdikcijos taisyklių taikymo išplètimas susijęs su susitarimų dèl teismingumo veiksmingumo didinimu. Žaliojoje knygoje Komisija pagrįstai akcentavo, kad susitarimui dẻl teismingumo turi būti suteikiamas visiškas veiksmingumas, nes jie, be kita ko, svarbūs tarptautiniuose komerciniuose santykiuo-

27 Šiam tikslui turètų tarnauti jau nuo 1992 metų rengiamas Sprendimų projektas, angl. „The Jugdements project“ [interaktyvus]. Prieiga internete: http://www.hcch.net/ index_en.php?act=text.display\&tid=149 [žiūrèta 201401 07, 11 val. 20 min.]. 
$\mathrm{se}^{28}$. Komisija pabrèžè, kad svarbu atrasti būdą, kaip didinti šių susitarimų veiksmingumą, ypač kai teismo procesai vyksta paraleliai, nes šie susitarimai dažnai buvo įrankis vilkinti teismo procesą ${ }^{29}$. Komisija pateikẻ keletą pasiūlymų, kurių dalis perkelti ị Reglamento Nr. 1215/2012 nuostatas. Komisija siūlè, kad (1) susitarime nurodytam teismui būtų leidžiama nesilaikyti lis pendens apribojimo sustabdyti bylos nagrinèjimą, (2) prioriteto taisyklę taikyti teismui, nurodytam susitarime, nustatant, kad jis turi prioritetą nustatyti, ar egzistuoja jurisdikcija, o kiti teismai iki tokio sprendimo turètų stabdyti procesą, (3) nedarant įtakos lis pendens taisyklès taikymui siūlyta nustatyti tiesioginio bendradarbiavimo ir kooperavimosi tarp dviejų teismų procedūrą, (4) nustatyti pareigą atlyginti nuostolius, kylančius dèl tokių susitarimų nesilaikymo, (5) netaikyti lis pendens taisyklès, kai paralelinis teismo procesas vyksta dẻl ginčo apimties arba dẻl konstatuojamojo pobūdžio sprendimo (ang. declaratory relief) prièmimo, arba nustatyti senaties terminą ieškiniui dèl reikalavimo ribų tuo atveju, jei konstatuojamojo pobūdžio sprendimas būtų nepalankus, (6) nustatyti standartinę susitarimo dèl jurisdikcijos formą, tai pagreitintų teismų sprendimų dẻ jurisdikcijos buvimo (ar nebuvimo) prièmimą ${ }^{30}$.

Komisija, siekdama efektyvinti ir greitinti teismo procesą, siūlè, kad tuo atveju, kai šalys nurodẻ konkretų teismą ar teismus jų ginčui nagrinèti, pasirinktajam teismui suteikiama pirmenybè spręsti dèl savo jurisdikcijos, nesvarbu, byla jame iškelta pirmiau ar veliau; tokiu atveju bet kuris kitas teismas turi sustabdyti bylos nagrinejjimą, kol pasirinktasis teismas konstatuos arba, jei susitarimas negalioja, paneigs savo jurisdikciją ${ }^{31}$ Komisija pasiūlyme pateikè ir suderintą kolizinę nor-

28 Žalioji knyga dèl Tarybos reglamento (EB) Nr. 44/2001 dèl jurisdikcijos ir teismo sprendimų civilinėse ir komercinèse bylose pripažinimo ir vykdymo priežiūros COM (2009) 175 galutinis [interaktyvus]. Prieiga internete: http://ec.europa.eu/justice/ newsroom/civil/opinion/files/090630/green_paper_en.pdf [žiūrèta 201506 12, 17 val. $20 \mathrm{~min}$.$] .$

29 Tokie atvejai literatūroje įvardijami kaip ,itališkos torpedos“, kai esant susitarimui dèl teismingumo, viena šalis, žinodama, kad gali sulaukti ieškinio, kreipiasi ị teismą, kuris neturi jurisdikcijos nagrinèti ginčą; pasirenkamas teismas toje valstybejje narejje, kurioje teismo procesas trunka kuo ilgiau. Tada kita šalis, kuri kreipiasi i teismą, nurodytą šalių susitarime, turi laukti, kol pirmasis teismas išspręs savo jurisdikcijos klausimą. Jei sprendimas bus skundžiamas instancine tvarka, tai gali užtrukti keletą metų.

30 Žalioji knyga dèl Tarybos reglamento (EB) Nr. 44/2001 dèl jurisdikcijos ir teismo sprendimų civilinèse ir komercinèse bylose pripažinimo ir vykdymo priežiūros COM (2009) 175 galutinis [interaktyvus]. Prieiga internete: http://ec.europa.eu/justice/ newsroom/civil/opinion/files/090630/green_paper_en.pdf [žiūrèta 201506 12, 18 val. $10 \mathrm{~min}$.$] .$

312010 m. gruodžio 14 d. KOM (2010) 748 galutinis [interaktyvus]. Prieiga internete: http://eur-lex.europa.eu/legal-content/EN/TXT/?qid=1419152097677\&uri=CELEX:5 2010 PC0748 [žiūrèta 20150107,12 val. 40 min.]. 
mą, reglamentuojančią materialinį susitarimų dẻl teismingumo galiojimą, taip užtikrinant panašų rezultatą nepaisant to, kuriame teisme byla iškelta.

Reglamentas Nr. 1215/2012 igyvendino Komisijos siekị ir išplète susitarimų dèl teismingumo galiojimą, kadangi pagal 25 straipsnio 1 dalị susitarimas dẻl teismingumo galioja nepaisant to, ar bent viena iš jo šalių turi nuolatinę gyvenamają vietą ES valstybejje nareje. Be to, 25 straipsnio 5 dalyje ịtvirtinama nuostata, kad susitarimas dèl jurisdikcijos, kuris yra sutarties dalis, laikomas nuo kitu sutarties sąlygų nepriklausomu susitarimu, taigi pagrindinès sutarties negaliojimas nereiškia tokio susitarimo negaliojimo. Tuo atveju susitarimas dẻl jurisdikcijos yra niekinis, turi būti vadovaujamasi pasirinkto teismo ar teismų lex fori nuostatomis, iskaitant kolizines normas ${ }^{32}$.

\subsubsection{Lis pendens taisykle ir jos išimtis, remiantis Reglamento Nr. 1215/2012 nuostatomis}

Reglamento Briuselis I 27 straipsnis, kuris nustate, kad ,jeigu skirtingų valstybių narių teismuose iškeliamos bylos tuo pačiu ieškinio pagrindu ir tarp tų pačių šaliu, bet kuris teismas, kitas nei teismas, kuriame buvo iškelta pirmoji byla, savo iniciatyva sustabdo bylos procesą, kol nustatoma pirmojo iškèlusio bylą teismo jurisdikcija“"33. Reglamente Nr. 1215/2012 nustatyta, kad „teismo, ị kurị kreiptasi dèl ginčo, prašymu, bet kuris kitas teismas, ị kurị buvo kreiptasi, nedelsdamas informuoja pirmaji teismą apie datą, kai i ji buvo kreiptasi“. Šis reglamentavimas skirtas tam, kad teismai galètų tinkamai vykdyti lis pendens taisyklès reikalavimus, be to, Komisijai buvo teikiami nusiskundimai dẻl to, kad tokia informacija neprieinama (Cadet, 2013, p. 221).

Tačiau tuo atveju, kai šalys turi sudariusios susitarimą dèl teismingumo, nustatyta išimtis šiai pirmenybès taisyklei: nepaisant to, į kurị teismą kreiptasi pirmiausia, pirmas klausimą dèl savo jurisdikcijos turi spręsti teismas, nurodytas šalių susitarime. Kai pastarasis teismas nustato savo jurisdikciją, bet kuris kitos valstybės narès teismas atsisako savo jurisdikcijos pirmojo teismo naudai ${ }^{34}$.

Reglamentas Nr. 1215/2012 nustato naujas taisykles, reglamentuojančias lis pendens taisyklès taikymą, kai susijusi byla nagrinejjama trečiosios valstybės teisme. Šios taisyklès taikomos tik tada, kai teismo jurisdikcija nustatyta remiantis bendrosiomis arba specialiosiomis jurisdikcijos taisyklëmis. Reglamento 33 straipsnis reglamentuoja situaciją, kai trečiosios valstybès teisme nagrinèjant bylą, valstybės narès teisme pradedamas procesas byloje tarp tų pačių šalių, dèl to paties dalyko ir tuo pačiu pagrindu, o 34 straipsnio nuostatos skirtos situacijai, kai valstybės narès

32 Reglamento Nr. 1215/2001 20 konstatuojamoji dalis.

33 Briuselis I, 27 straipsnio 1 dalis.

34 Reglamento Nr. 1215/2001 31 straipsnio 3 dalis. 
teisme iškeliama byla, susijusi su trečiosios valstybès teisme nagrinejjama byla. Abiem šiais atvejais valstybès narès teismui suteikiama teisè sustabdyti bylos nagrinèjimą, tam turètų egzistuoti 2 sąlygos: pirma, teismas turi tikètis, kad trečiojoje valstybejje priimtą teismo sprendimą bus galima pripažinti ir, prireikus, vykdyti toje valstybeje nareje ir antra, valstybès narès teismas turi būti ịsitikinęs, kad toks bylos sustabdymas būtinas siekiant tinkamai vykdyti teisingumą. Atkreiptinas dèmesys, kad toks bylos sustabdymas - valstybès narès teismo teisè, jei egzistuoja tam tikros prielaidos, bet tai - ne pareiga. Šiomis nuostatomis siekiama suteikti lankstumo valstybės narès teismams, kai pasirodo, kad trečiosios valstybės teismas yra tinkamesnè (labiau susijusi) vieta nagrinèti bylą (Cadet, 2013, p. 221), be to, tokios taisyklès turètų padèti išvengti dviejų skirtingų sprendimų byloje tarp tų pačių šalių ir dèl to paties pagrindo prièmimo. Siekiant išvengti laike neapriboto bylos nagrinejimo sustabdymo, Reglamente Nr. 1215/2012 taip pat nustatyta, kada valstybės narès teismas gali atnaujinti bylos nagrinejjimąa ${ }^{35}$.

\subsubsection{Kitos Reglamentu Nr. 1215/2012 įtvirtinamos naujovés, susijusios} su teismu jurisdikcija

Reglamento Nr. 1215/2012 7 straipsnio 4 punkte ịtvirtinama nauja jurisdikcijos taisyklè, taikytina reikalavimams grąžinti kultūros objektus, kuriuos pateikia asmuo, teigiantis, kad turi teisę reikalauti grąžinti toki objektą. Laikantis šios nuostatos, prieš asmeni gali būti pradètas teismo procesas kitoje nei jo nuolatinè (buveinès) gyvenamoji vieta valstybejje nareje, jei reikalavimo pareiškimo metu kultūros objektas yra toje valstybejje narejje, ị kurios teismą yra kreipiamasi. Ši nuostata ị Reglamentą Nr. 1215/2012 ịtraukta jị svarstant ir galimai susijusi su 1995 m. birželio 24 d. Unidroit konvencija dèl pavogtų ar nelegaliai eksportuotų kultūros objektų grąžinimo ${ }^{36}$, be to, glaudžiai siejasi su 1993 m. kovo 15 d. Tarybos direktyva Nr. 93/7/EEB dèl neteisètai iš valstybių narių teritorijos išvežtų kultūros objektų ${ }^{37}$. Ši nauja taisyklè turètų palengvinti kultūros objektų susigrąžinimą, nes teismas, ị kurị kreiptasi, turès teisę taikyti laikinąsias apsaugos priemones.

Reglamente Nr. 1215/2012 taip pat papildyta atvykimo ị teismą, kaip jurisdikcijos pripažinimo, taisyklè: 26 straipsnio 2 dalis nustato, kad kai atsakovas yra

35 Valstybès narès teismas gali tęsti bylos nagrinėjimą jeigu: (i) trečiosios valstybès teisme bylos nagrinėjimas yra sustabdytas arba nutrauktas, valstybės narės teismas mano, kad mažai tikètina, jog procesas trečiosios valstybès teisme bus užbaigtas per pagrịstą laiką arba (iii) būtina tęsti bylos nagrinejjimą, siekiant tinkamai vykdyti teisingumą.

36 Lietuvoje ratifikuota 1997 m. sausio 29 d., VŽ, 1997-01-29, Nr. 8-139.

37 OL L 1993, p. 74. 
draudejjas, apdraustasis, draudimo sutarties naudos gavejjas, žalą patyrusi šalis, vartotojas arba darbuotojas, teismas, prieš prisiimdamas jurisdikciją tuo pagrindu, kad atsakovas atvyko ị teismą, užtikrina, kad atsakovas būtų informuotas apie savo teisę ginčyti teismo jurisdikciją ir apie atvykimo ar neatvykimo ị teismą pasekmes. Tokia nuostata atskleidžia Europos Sajungos bendradarbiavimo teisingumo srityje keliamą tikslą - užtikrinti, kad visi asmenys, dalyvaujantys vidaus rinkoje, nepaisant to, kad dalis jų neturi specialių teisinių žinių ar profesionalaus atstovo, turètų galimybę ị efektyvią ir prieinamą teisinę gynybą, kai byla susijusi daugiau nei su viena valstybe nare.

\section{Lietuvoje taikytinas specialus Reglamento Nr. 1215/2012 igyvendinimo reguliavimas}

Nors SESV 288 straipsnio 2 dalis nustato, kad „Reglamentas yra taikomas visuotinai. Jis privalomas visas ir tiesiogiai taikomas visose valstybėse narèse“, Lietuvos Respublikoje nuo 2008 m. lapkričio 29 d. galioja specialus „Lietuvos Respublikos civilini procesą reglamentuojančių Europos Sajungos ir tarptautinès teisès aktų igyvendinimo ịstatymas“", nustatantis tam tikras ES reglamentų igyvendinimo taisykles. Rengiantis Reglamento Nr. 1215/2012 įsigaliojimui Lietuvoje, 2014 m. gegužès 15 d. priimtas Lietuvos Respublikos Civilinị procesą reglamentuojančių Europos Sajungos ir tarptautinès teisès aktų ịgyvendinimo įstatymo Nr. X-1809 ketvirtojo skirsnio pavadinimo, 4, 15 straipsnių ir priedo pakeitimo ir įstatymo papildymo ketvirtuoju ${ }^{1}$ ir devintuoju ${ }^{3}$ skirsniais įstatymas ${ }^{638}$. Šio įstatymo pakeitimai, t. y. ketvirtasis ${ }^{1}$ skirsnis, nustato Lietuvos apeliacinio teismo kompetenciją nagrinèti šiuos prašymus: (i) prašymus priimti sprendimą, kad nèra pagrindų atsisakyti pripažinti teismo sprendimą, taip pat prašymus peržiūrèti šiuos sprendimus; (ii) prašymus atsisakyti vykdyti teismo sprendimą. Prašymas peržiūrèti priimtą sprendimą, taip pat apeliacinis skundas dèl sprendimų dẻl atsisakymo vykdyti teismo sprendimą turi būti paduodami per 30 dienų nuo nutarties įteikimo šaliai dienos, o tuo atveju, kai šalies, turinčios teisę teikti prašymą ar apeliacinị skundą, nuolatinė gyvenamoji vieta yra ne Lietuvos Respublikoje, jai suteikiamas 60 dienų terminas.

38 Lietuvos Respublikos Civilinį procesą reglamentuojančiu Europos Sajungos ir tarptautinès teisès aktu igyvendinimo įstatymo Nr. X-1809 ketvirtojo skirsnio pavadinimo, 4, 15 straipsnių ir priedo pakeitimo ir ịstatymo papildymo ketvirtuoju ${ }^{1}$ ir devintuoju ${ }^{3}$ skirsniais įstatymas, 2014 m. gegužès 15 d., Nr. XII-890. 


\section{Ar Reglamentas Nr. 1215/2012 sudarẻ sąlygas piliečiams ir įmonėms lengviau ginti savo teises ES teismuose?}

Komisija, pateikdama Pasiūlymą dèl Reglamento Briuselis I pakeitimo, Poveikio vertinimo ataskaitoje ${ }^{39}$ nurodè, kad $2009 \mathrm{~m}$. Stokholmo programa deklaravo siekị toliau plèsti Europos teisingumo erdvę užtikrinant, kad vis dar egzistuojantys apribojimai asmenų ir įmonių teisių gynimui tarp valstybių narių būtų panaikinti. Tai reiškè, kad sprendimai civilinèse ir komercinèse bylose turètų būti igyvendinami tiesiogiai kitoje valstybeje nareje be tam numatytų tarpinių priemonių, o asmenų ir įmonių teisė pasinaudoti teismine gynyba turètų būti supaprastinta taip, kad sudarytu asmenims galimybę igyvendinti savo teises visoje Europos Sajungoje. Taigi Europos Komisija, teikdama savo pasiūlymą, siekẻ igyvendinti šiuos tikslus. Todèl tikslinga pabandyti įvertinti, ar Reglamento Nr. 1215/2012 nuostatos iš tikrujų supaprastina valstybių narių piliečių ir ịmonių galimybes kreiptis ị teismą kitoje valstybèje nareje ar ịvykdyti jų naudai priimtą teismo sprendimą.

Egzekvatūros panaikinimas neabejotinai reiškia, kad sprendimų įvykdymas kitose valstybėse narèse tuo suinteresuotiems kreditoriams tampa paprastesnis, nes nereikia privalomai kreiptis ị teismą dèl to sprendimo pripažinimo. Tačiau papildomo proceso išvengiama tik tuo atveju, jei skolininkas nepasinaudoja savo Reglamento 45 straipsnyje įtvirtinta teise prašyti nepripažinti teismo sprendimo. Taigi dẻl dalies vienoje valstybèje priimtų teismo sprendimų vykdymo kitoje valstybėje nareje kreditoriui vis dar išlieka papildomo proceso tikimybe ir su tuo susijusios išlaidos.

Pripažintina, kad Reglamentas Nr. 1215/2012 atsakovų, kurie yra draudèjai, apdraustieji, draudimo sutarties naudos gavèjai, žalą patyrusios šalys, vartotojai arba darbuotojai, interesų apsaugą pagerino ta prasme, kad 26 straipsnio 2 dalis dabar aiškiai ịpareigoja bylą nagrinèjantị teismą, kuris pagal Reglamento Nr. 1215/2012 taisykles neturi jurisdikcijos tokią bylą nagrinèti, ị teismą atvykusiam atsakovui išaiškinti jo teisę ginčyti teismo jurisdikciją, taip pat atsakovo atvykimo ar neatvykimo ị teismą pasekmes ${ }^{40}$. Reglamento Briuselio I 24 straipsnis numate, kad be teismo, numatyto reglamente Briuselis I, jurisdikciją nagrinèti turi

39 Poveikio vertinimo ataskaita - tai Europos Komisijos atliekamas vertinimas dél naujos iniciatyvos reikalingumo, kurioje vertinamas veiksmu poreikis ES lygmeniu, taip pat ekonominè, socialinè ir aplinkosauginè galimos iniciatyvos ir jos alternatyvų itaka. Plačiau tai aprašo $2015 \mathrm{~m}$. gegužès $19 \mathrm{~d}$. Komisijos darbinis dokumentas Nr. SWD(2015) 111 final „Geresnio reguliavimo gairès“, p. 9 [interaktyvus]. Prieiga internete: http://ec.europa.eu/smart-regulation/guidelines/docs/swd_br_guidelines en.pdf [žiūrèta 201509 12, 19 val. 14 min.].

40 Būtinybę ịsitikinti, kad atsakovas suvokia „atvykimo“ pasekmes Reglamento Nr. 1215/2012 prasme, pažymi ir Y. Bot savo $2014 \mathrm{~m}$. balandžio $2 \mathrm{~d}$. išvadoje byloje A. v. B. ir kt., bylos Nr. C-112/13. 
ir tas teismas, ị kurị atvyksta atsakovas ${ }^{41}$, tačiau atsakovui, kuris neturi specialiu teisès žinių, nebuvo žinomos atvykimo ị teismą teisinès pasekmès, t. y. kad tokiu atveju jo atvykimas laikomas jurisdikcijos neturinčio teismo jurisdikcijos pripažinimu. Taigi, nors atsakovui, neturinčiam specialių teisinių žinių, neįmanoma pasirinkti teismo vietos, kurioje vykstantis teismo procesas užtikrintų geriausią jo interesų apsaugą, tačiau Reglamente Nr. 1215/2012 įtvirtintas reglamentavimas leis užtikrinti, kad atsakovas pats priimtų sprendimą, kuriame teisme jis pageidauja dalyvauti procese.

Nors Reglamentas Nr. 1215/2012 nustato jurisdikcijos taisykles, tačiau konkretus valstybės narès teismas, turintis jurisdikciją, turès būti nustatomas pagal konkrečias nacionalinès teisès taisykles. Manytina, kad praktiškai fiziniam asmeniui ar mažai / vidutinei įmonei apginti savo teises be kvalifikuoto teisininko pagalbos, kai jurisdikciją turès kitos valstybès narès teismas, vis dar išlieka sudètinga, nes būtinos ne tik specialios teisès žinios nustatant teismingumą pagal Reglamento Nr. 1215/2012 nuostatas, bet ir kitos teisès sistemos žinios, nustatant konkretaus teismo kitoje valstybejje narëje jurisdikciją. Net ir teikiant prašymus išduoti Europos mokejimo ịsakymą pagal 2006 m. gruodžio 12 d. Europos Parlamento ir Tarybos reglamentą (EB) Nr. 1896/2006 $6^{42}$, kurio 6 straipsnis nustato, kad jurisdikcija prašymų dèl Europos mokẻjimo ịsakymų padavimo pirmiausiai nustatoma pagal Reglamentą Nr. 2015/2012, reikia specialių kabos žinių, nes, kaip nurodo Europos teisminis atlasas civilinèse bylose, ne visos valstybės pripažįsta anglų kalbą pildant šiuos prašymus ${ }^{43}$.

Tenka apgailestauti, kad Reglamentu Nr. 1215/2012 neįtvirtintas Komisijos deklaruotas tikslas gerinti arbitražinių susitarimų veiksmingumą ir ịtvirtinti taisykles, kurios leistų išvengti lygiagrečiai vykstančių procesų ir piktnaudžiavimo bylinèjimosi taktikomis (Komisijos pasiūlymo 22 preambulès punktas). $2011 \mathrm{~m}$. birželio 28 d. Europos Parlamentas savo ataskaitoje nurodè atsisakyti šiems tikslams igyvendinti skirtos Komisijos pasiūlymo 29 straipsnio 4 dalies nuostatos, nurodydamas, kad nepritaria net daliniam išimties dèl arbitražo Reglamente Nr. 1215/2012 atsisakymui. Issigaliojusio Reglamento Nr. 1215/2012 12 preambulès dalis įtvirtina reglamento taikymo išimtị arbitražui, tokia situacija sukuria prielaidas, kad teismo sprendimas, kuriuo bus konstatuojamas arbitražinès išlygos

$41 \quad$ Ši taisyklè negalioja tuo atveju, jei atsakovas ị teismą atvyksta siekdamas užginčyti jurisdikciją arba jeigu kitas teismas turi išimtinę jurisdikciją, tai nustatyta reglamento Briuselis I, 24 straipsnyje ir Reglamento Nr. 1215/2012 26 straipsnio 2 dalyje.

42 OL C 12, 2001.01.15, p. 1.

43 Europos civilinis atlasas civilinėse bylose prieinamas internete: http://ec.europa.eu/ justice_home/judicialatlascivil/html/epo_communicationshtml_it_lt.htm. Iš pateiktos informacijos matyti, kad, pavyzdžiui, Austrija priimtina laiko tik vokiečių kalbą, Italija tik italų. 
negaliojimas / neịmanomumas ịvykdyti, negalès būti pripažịstamas pagal Reglamento Nr. 1215/2012 taisykles. Tokia išimtis neleis artimiausiu metu pasiekti didesnio arbitražinių susitarimų efektyvumo ir ịgyendinimo didinimo.

Svarbu paminèti, kad kai kuriuos praktinius sunkumus, kurių kyla asmenims, siekiantiems kreiptis ị teismą kitoje valstybẻje narèje, Europos Komisija jau sprendžia, pavyzdžiui, siekiama įtvirtinti, kad kreipiantis dèl Europos Mokèjimo įsakymo ar norint pateikti Europos ieškinị dẻl nedidelès sumos kitoje valstybèje narèje, žyminį mokestị ir kitus teismo mokesčius būtų galima sumokèti kredito kortele arba elektroninio mokẻjimo būdu ${ }^{44}$. Valstybès narès tokiu reglamento pakeitimu būtų ịpareigotos įdiegti nuotolinio mokèjimo priemones, bent jau galimybę mokèti banko pavedimu ir kredito ar debeto kortelèmis mokejjimo internetu sistemose. Tai, be abejo, susiję su bylinèjimosi (šiuo atveju - banko mokesčių) išlaidomis, tačiau leis išvengti tokių situacijų, kai galimybė kreiptis ị teismą apribota vien jau tuo pagrindu, kad nèra galimybės sumokèti žyminio mokesčio nenukeliavus ị šalị arba jam sumokèti reikia samdyti advokatą kitoje valstybèje narejje ${ }^{45}$.

\section{Išvados}

Nors Komisijos pasiūlymai buvo daug radikalesni, Reglamentas Nr. 1215/2012 ịtvirtina nedaugelị pakeitimų, susijusių su jurisdikcijos nustatymu ar lis pendens taisyklès taikymu. Dalis nepriimtų pakeitimų gali būti paprastai paaiškinta, pavyzdžiui, valstybės narès neturejo poreikio skubiai suvienodinti ir vienašališkai nustatyti jurisdikcijos taisykles asmenims iš trečiųjų šalių, nes, viena vertus, tai nèra pagrindinès problemos, su kuriomis susiduria ES valstybių narių piliečiai, kita vertus, toks vienašališkas jurisdikcijos taisyklių nustatymas nebūtinai bus abipusiai pripažintas trečiųjų valstybių narių ir praktiškai veiksmingas.

Be abejo, teismų sprendimų judejjimas tarp valstybių narių palengvinamas ịtvirtinus egzekvatūros atsisakymą, be to, ịtvirtinta galimybė be papildomos procedūros taikyti laikinąsias apsaugos priemones, priimtas vienoje valstybejje nareje,

442013 m. lapkričio 19 d. Europos Komisijos pasiūlymas Nr. KOM (2013)794 dèl Europos Parlamento ir Tarybos Reglamento (EB) Nr. 861/2007, sukuriančio Europos ieškinių dèl nedidelių sumų procedūrą ir $2006 \mathrm{~m}$. gruodžio $12 \mathrm{~d}$. Europos Parlamento ir Tarybos reglamento Nr. 1896/2006 dèl Europos mokèjimo ịsakymo papildymo.

${ }_{45}$ Kaip nurodoma Komisijos parengtoje poveikio ataskaitoje, kai kuriose valstybėse reikalaujama, kad asmuo sumokètų žyminị ar kitus susijusius mokesčius asmeniškai atvykdamas ị teismą arba šiam tikslui samdytų advokatą, arba mokèjimai priimami čekiais, kurie apskritai nepaplitę valstybėse narėse (kaip pavyzdžiai pateikiami Graikija, Bulgarija, Olandija, Didžioji Britanija). 2013 m. lapkričio 19 d. Komisijos darbinis dokumentas Poveikio vertinimo ataskaita Nr. SWD(2013) 459 galutinè, [interaktyvus]. Prieiga internete: http://eur-lex.europa.eu/legal-content/EN/TXT/PDF/?uri=CELEX:5 2013SC0459\&from=en [žiürèta 201509 27, 11 val. 50 min.]. 
ten, kur yra atsakovo turtas. Atkreiptas dėmesys, kodèl toks laikinujų apsaugos priemonių judèjimas praktikoje nebus paprastas, tačiau tai svarbus ES žingsnis link dar glaudesnio teismų bendradarbiavimo ir efektyvesnio ES piliečių bei juridinių asmenų teisių gyvinimo vieningoje teisingumo erdvejje.

Svarbu, kad Reglamente Nr. 1215/2012 įtvirtinta teismų pareiga paaiškinti tam tikros rūšies atsakovams, kokias teisines pasekmes lemia atvykimas ị jurisdikcijos neturintị teismą Reglamento Nr. 1215/2012 prasme: tai, be abejo, padeda geriau ginti jų interesus.

Reglamento Nr. 1215/2012 trūkumu galima laikyti tai, kad ir toliau liko galioti arbitražo išimtis ir jis netaikomas jokiems su arbitražu susijusiems sprendimams. Kadangi arbitražas - populiarus civilinių ir komercinių ginčų tarp privačių šalių sprendimo būdas, reikia tikètis, kad ateityje ši išimtis bus panaikinta, taip tik ịtvirtinant Reglamentą Nr. 1215/2012 kaip efektyvaus teismų sprendimų pripažinimo ir vykdymo instrumentą.

Nors apskritai reformuojant teismų sprendimų pripažinimą ir vykdymą civilinėse bei komercinėse bylose pakeitimų, vertinant šį dokumentą atskirai nuo kitų dokumentų, nebuvo daug, svarbu tai, kad Reglamentas Nr. 1215/2012 - tik didelès teisinių instrumentų, reglamentuojančių bendradarbiavimą civilinèse ir komercinèse bylose, dalis. Be abejo, Reglamentas Nr. 1215/2012 taikomas kartu su 2014 m. gegužès 15 d. Europos Parlamento ir Tarybos Reglamentu (ES) Nr. 655/2014, kuriuo nustatoma europinio sąskaitos blokavimo ịsakymo procedūra, siekiant palengvinti tarpvalstybinị skolų išieškojimą civilinèse ir komercinèse bylose, leis sukurti efektyvią kreditoriaus teisių apsaugą. Be to, jei Europos Taryba ir Parlamentas pritars 2013 m. lapkričio 19 d. Europos Komisijos pasiūlymui Nr. KOM (2013)794 dèl Europos Parlamento ir Tarybos Reglamento (EB) Nr. 861/2007, sukuriančio Europos ieškinių dèl nedidelių sumų procedūrą ir $2006 \mathrm{~m}$. gruodžio $12 \mathrm{~d}$. Europos Parlamento ir Tarybos reglamento Nr. 1896/2006 dèl Europos mokẻjimo ịsakymo papildymo, naudojantis šiais dviem instrumentais (Europos mokejjimo ịsakymu ir ieškiniu dèl neginčytinų sumų priteisimo), bylinètis bus paprasčiau ir pigiau.

Nors Reglamentas Nr. 1215/2012 yra tik vienas iš daugelio instrumentų teisminio bendradarbiavimo civilinèse ir komercinèse bylose srityje, kurioje Europos Komisija veikia ypač aktyviai, juo priimti pakeitimai turètu prisidèti prie paprastesnio teismų sprendimų judejimo tarp valstybių narių. Kitas žingsnis - laukti praktinių šio reglamento taikymo situacijų ir naujos Europos Sajungos Teisingumo Teismo praktikos. Šie sprendimai leis ịvertinti, kaip Reglamentas Nr. 1215/2012 veikia praktiškai ir kokie nauji iššūkiai kyla juo besinaudojantiesiems. 


\section{Rūta Bučinskaitè}

\section{Literatūra}

\section{Monografijos, moksliniai straipsniai ir kita literatūra}

Alio, T. (2014). Die Neufassung der Brüssel I-Verordnung. Neue Juristische Wochenschrift (NJW) 33: 2395-2400.

Basedow, J. (2000). Private Law in the International Arena: from National Conflict Rules towards Harmonization and Unification, liber amicorum Kurt Siehr. Haga: TMC Asser Press.

Cadet, F. (2013). Main features of the revised Brussels I Regulation. Europäische Zeitschrift für Wirtschaftsrecht $(E u Z W): 218-223$.

Europos Komisijos darbinis dokumentas „Poveikio vertinimo ataskaita“ Nr. SWD(2013) (2013 11 19). Prieiga internete: http://eur-lex.europa.eu/legal-content/EN/TXT/PDF/?uri=CELEX:52013SC0459\&from=en

Europos Komisijos Pasiūlymas dèl Europos Parlamento ir Tarybos reglamento dẻl jurisdikcijos ir teismo sprendimų civilinėse ir komercinėse bylose pripažinimo ir vykdymo. (2010). Gruodžio 10 d. KOM(2010) 748 galutinis.

Europos Komisijos Pasiūlymas dèl Europos Parlamento ir Tarybos reglamento dèl jurisdikcijos ir teismo sprendimų civilinėse ir komercinèse bylose pripažinimo ir vykdymo. (2010). Gruodžio 10 d. KOM(2010) 748 galutinis.

Europos Komisijos Žalioji knyga dèl Tarybos reglamento (EB) Nr. 44/2001 dèl jurisdikcijos ir teismo sprendimu civilinèse ir komercinèse bylose pripažinimo ir vykdymo priežiūros. (2009). Balandžio 21 d. Prieiga internete: http://ec.europa.eu/justice/newsroom/civil/opinion/files/090630/green_paper_en.pdf

Hess, B., Pfeiffer, T., Schlosser, P. (2007). Report on the application of Brussels I regulation in the Member States. Prieiga internete: http://ec.europa.eu/civiljustice/news/docs/study_application_brussels_1_en.pdf

Hess, B., Pfeiffer, T., Schlosser, P. (2008). The Brussels I Regulation 44/2001: application and enforcement in the $E U$. München: C. H. Beck.

Komisijos tarnybų darbinis dokumentas „Poveikio vertinimo ataskaita“. (2010). Gruodio 14 d. Prieiga internete: http://ec.europa.eu/justice/policies/civil/docs/sec_2010_1547_en.pdf

Lietuvos Respublikos teisingumo ministerijos nuomonè dèl Žaliosios knygos, Nr. (1.11) 7R-5198. (2009). Liepos 7 d. Prieiga internete: http://ec.europa.eu/justice/newsroom/civil/opinion/090630_en.htm

Maher, G., Roger, B. J. (1999). Provisional and protective remedies: the British experience of the Brussels convention. International and Comparative Law 48: 302-329.

Palsson, L. (2000). Interim Relief under the Brussels and Lugano Conventions. Private Law in the International Arena: from National Conflict Rules towards Harmonization and Unification, liber amicorum Kurt Siehr: 621-638. Haga: TMC Asser Press.

Rauscher, T. (2006). Europäisches Zivilprozessrecht, Kommentar. 2 Auflage. European Law Publishers.

Stokholmo programa - atvira ir saugi Europa piliečių labui ir saugumui, priimta Europos Vadovų Tarybos. (2010). Gegužès 4 d. $O L$ C 115: 1-38.

Studija dèl tikslingumo Europos Sajungai ratifikuoti Hagos konvenciją dèl teismo pasirinkimo susitarimu. (2007). Prieiga internete: http://ec.europa.eu/justice/civil/files/ia_choice_courts_agreement_en.pdf

Studija dèl nacionaliniu jurisdikcijų taisykliu, kai atsakovas negyvena valstybèje nareje. (2007). Prieiga internete: http://ec.europa.eu/civiljustice/news/docs/study_residual_jurisdiction_en.pdf

Teisès aktai

$1968 \mathrm{~m}$. rugsejjo $27 \mathrm{~d}$. Briuselio konvencija dèl jurisdikcijos ir sprendimų civilinėse ir komercinėse bylose vykdymo. OJ L 299, 1972-12-31.

1997 m. spalio 2 d. Amsterdamo sutartis. OL C 340, 1997-11-10.

2000 m. gruodžio 22 d. Tarybos reglamentas Nr. 44/2001 dèl jurisdikcijos ir teismo sprendimų civilinèse ir komercinėse bylose pripažinimo ir vykdymo. OL L 12/1-12/26.

2003 m. gruodžio 9 d. Europos Sajungos Teisingumo Teismo sprendimas, priimtas byloje Nr. C-184/10. (2003). Grasser, ECR, I-14693.

2004 m. balandžio 27 d. Europos Sajungos Teisingumo Teismo sprendimas, priimtas byloje Nr. 159/02, Turner, ECLI:EU:C:2004:228.

2007 m. lapkričio 13 d. Europos Parlamento ir Tarybos reglamentas (EB) Nr. 1393/2007 dèl teisminių ir neteisminių dokumentų civilinėse ir komercinėse bylose ịteikimo valstybèse narèse (dokumentų įteikimas), panaikinantis Tarybos reglamentą (EB) Nr. 1348/2000. OJ L 324, 2007.12.10, p. 79-120. 
2008 m. lapkričio 29 d. Lietuvos Respublikos civilinį procesą reglamentuojančių Europos Sajungos ir tarptautinès teisès aktų ígyvendinimo ịstatymas, Nr. X-1809. (2008). Valstybès žinios, Nr. 137-5366.

2009 m. birželio 25 d. Europos Sajungos Teisingumo Teismo sprendimas, priimtas byloje Nr. C-14/08. (2009). Roda Golf \& Beach Resort SL. ECLI:EU:C:395.

2012 m. kovo 15 d. Europos Sajungos Teisingumo Teismo sprendimas, priimtas byloje Nr. C292/10. (2012). G. V. Cornelius de Visser, ECLI:EU:C:2012:142.

2012 m. gruodžio 12 d. Europos Parlamento ir Tarybos reglamentas Nr. 1215/2012 dèl jurisdikcijos ir teismo sprendimų civilinèse ir komercinèse bylose pripažinimo ir vykdymo. OL L 351/1-351/35.

2012 m. gruodžio 19 d. Europos Sajungos Teisingumo Teismo sprendimas, priimtas byloje Nr. C325/11. Adler, ECLI:EU:C:2012:824.

2014 m. gegužès 15 d. Europos Parlamento ir Tarybos reglamentas (ES) Nr. 542/2014, kuriuo dèl taisykliu, taikytinų dèl bendro patentų teismo ir Beniliukso teisingumo Teismo, iš dalies keičiamas Reglamentas (ES) Nr. 1215/2012. OL L 163/1-163/4.

2014 m. gegužès 15 d. Europos Parlamento ir Tarybos Reglamentas (ES) Nr. 655/2014, kuriuo nustatoma europinio sąskaitos blokavimo įsakymo procedūra, siekiant palengvinti tarpvalstybinį skolų išieškojimą civilinèse ir komercinèse bylose. (2014). OL 189, 2014.06.27: 59-93.

\section{EU INTEGRATION OPPORTUNITIES FOR CITIZENS AND BUSINESS: NEW REGULATIONS FOR COURT JUDGEMENT RECOGNITION AND ENFORCEMENT IN CIVIL AND COMMERCIAL MATTERS}

\section{Rūta Bučinskaitè}

\section{Summary}

The area of co-operation in civil and commercial matters has gained importance since the adoption of the Treaty of Amsterdam on 10 November 1997, when the competences for the EU in that area have been granted. Ever since, the European legislator has remained active in the area. The need for that was confirmed in 2009, when the European Council adopted the Stockholm programme which laid out the priorities in the area of justice, freedom, and security.

Regulation No. 1215/2012 that came into force on 10 January 2012 for all the EU member states (except for Denmark) shall implement some changes compared to Brussels Regulation No. 44/2001. However, the new rules which were adopted are not as ambiguous as those proposed by the European Commission on 14 December 2010, when the proposal for a regulation of the European Parliament and the Council on jurisdiction and the recognition and enforcement of judgments in civil and commercial matters was adopted.

The most important change that has been introduced is related to the abolition of exequatur for the decisions of the courts of the EU member states in civil and commercial matters. That implies that the judgments enforceable in one member state shall be enforceable in another member state without any procedures required. 
The rights of the debtor shall be safeguarded, while he shall have a right to request for the refusal of recognition in the member state where the recognition is foreseen. The refusal of recognition can be granted on the classical grounds, i.e. whenever the judgment shall be contrary to public policy, whenever it shall be issued in default of the appearance of the defendant, and whenever it is irreconcilable with the judgement among the same parties in the member state or among the same parties involving the same cause of action in any other member state.

The rules of jurisdiction remain the same as in the previous Regulation, however, a new rule is introduced in Part 2 of Article 21, in compliance with which the employer can be sued in the member state where the employee habitually performs his duties or in the member state where the company hired the employee. This rule shall definitely be helpful when initiating legal actions towards the third state defendants.

Regulation No. 1215/2012 lays out rules strengthening the agreements of the parties regarding jurisdiction: they shall be valid despite the domicile of the parties, and they shall be treated as a separate agreement, disregarding other terms of the contract. That will help to safeguard the agreement regarding jurisdiction and disregarding the validity of the entire contract.

Regulation No. 1215/2012 also provides a clear rule regarding the acceptance of jurisdiction by appearing in court in compliance with which the courts shall be obliged to explain legal consequences of the appearance in court for the jurisdiction in cases when the defendant is a weaker party of the contract (e.g. the injured, the employee, etc.).

In conclusion, Regulation No. 1215/2012 provides new rules which shall improve the circulation of judgements in civil and commercial matters. Regretfully, the operation of arbitration agreements shall not be improved, since the exception for arbitration agreements remains valid. It is to be expected that the operation of the judgments regarding provisional and protective measures shall provide challenges for lawyers and courts of the member states, since some protective or provisional measures unknown for national legal systems shall have to be introduced in the member state of execution in compliance with the national law. 